\title{
COMPARATIVE ASSESSMENT OF STRUT MODELS FOR THE MODELLING OF IN-PLANE SEISMIC RESPONSE OF INFILL WALLS
}

\author{
Laura Liberatore $^{1}$, Fabrizio Noto ${ }^{1}$, Fabrizio Mollaioli ${ }^{1}$ and Paolo Franchin ${ }^{1}$ \\ ${ }^{1}$ Department of Structural and Geotechnical Engineering, Sapienza University of Rome \\ Via Gramsci 53, 00197 Rome, Italy \\ \{laura.liberatore,fabrizio.mollaioli,paolo.franchin\}@uniroma1.it \\ fabrizio.noto@gmail.com
}

Keywords: Masonry Infill, Strut Models, Lateral Strength, Lateral Stiffness, Equivalent Width.

\begin{abstract}
The influence of infills on the seismic response of frame structures has long been recognised. Typically, stiffness and strength of the infill and connections between infill and frame are such that the infill affects the global seismic behaviour of the structure. Hence, the presence of infills should be considered in the analysis and design of new buildings and in the seismic assessment of existing ones. To this aim, simple models for infill walls, such as the equivalent diagonal no-tension strut model, have been developed in the last decades. The objective of the present study is to assess the validity of different strut models. To this aim, 162 experimental tests available in the literature are considered. The data set includes both reinforced concrete and steel frames, as well as confined masonry structures. The mechanical characteristics of masonry and the boundary conditions between frames and infills of the test specimens take into account a large set of situations, reflecting the great variability in the materials and in the construction techniques adopted in different countries. Moreover, the type of tests and the related results are not uniform; in some cases monotonic experiments are performed, whereas in other cases cyclic tests are carried out. As expected, the presence of different types of infill-frame systems results in a large scatter of the data. However, the comparison between experimental results and predictions show that, on the average, the infill strength can be adequately estimated by resorting to the strut model whereas major uncertainties are found for the stiffness prediction.
\end{abstract}




\section{INTRODUCTION}

Damage observed after moderate and strong earthquakes highlighted the influence of infills on the seismic response of frame structures. Regularly distributed infills may significantly contribute to withstand seismic actions, reducing the deformation demand and enhancing the energy dissipation capacity [1,2]. On the contrary, irregular arrangement of infills may be strongly detrimental, producing unfavourable distribution of plastic hinges, high demand of inelastic deformations and brittle failures. Therefore, the presence of infills should be considered in the design of new buildings and in the seismic assessment of existing ones. For this reason, in the last decades, the issue concerning the modelling of infills has gained a growing attention and different methods have been proposed and developed [3,4]. Such methods may be divided roughly into two categories according to whether they are based on micro-modelling or on macro-modelling approaches.

The former is based on a finite element representation of the frame and the infill. The response of the frame, the infill and their interface are described by means of proper constitutive relations. To reproduce the shear sliding of masonry mortar, several plasticity-based continuous interface models have been developed [5]. In general, this approaches are quite complex due to the large amount of information required [6]. On the contrary, macro-models, even though unable to capture local phenomena, are characterized by an advantageous simplicity. The equivalent diagonal no tension strut is one of the most used macro-model, being often adopted for in-plane seismic assessment of frame structures. This model was initially based on the observation that the compressive path in the masonry panel, due to horizontal loads, develops mainly along its diagonal. Therefore, a way of representing the stiffening and strengthening effect of the masonry infill is replacing the panel with an equivalent no tension strut acting along the compressive path $[7,8]$. The strut model may also be used, with opportune modifications, for perforated infills [9]. The width of the strut depends on different features, such as the extension of the region of interaction between masonry and frame. The ultimate strength of the infills depends also on the failure mechanism, which is somewhat difficult to predict being affected by many factors, such as the material properties, the dimensions of the system and the vertical stress in the panel. Multiple strut configurations have also been proposed with the aim of capturing the interaction between the infill panel and the frame (e.g. $[10,11])$. The multiple strut approach allows to account for the shear transmission in critical regions but the calibration of the required parameters is somewhat complex. The use of these methods is recommended for building not designed for seismic loads, having insufficient shear reinforcement and strong infills.

In this study, a comparison between different single strut models is performed, based on 162 experimental tests available in the literature. The database includes both reinforced concrete and steel frames, as well as confined masonry structures. The mechanical characteristics of masonry and the boundary conditions between frames and infills of the test specimens take into account a large set of situations, reflecting the great variability in the materials and in the construction techniques adopted in different countries. In the following sections, the selected models and the considered experimental tests are briefly presented. Afterword, the comparison between experimental and predicted values is reported in terms of lateral stiffness and strength of the masonry infill.

\section{STRUT MODELS}

Various relationships have been proposed to calculate the lateral strength and stiffness of the equivalent strut. The former is strictly related to the infill failure mode, which depends on several parameters, such as the aspect and slenderness ratios, the mechanical characteristics of 
masonry, the stiffness and strength of the surrounding frame. As observed by Haldar et al. [12], four main failure modes have been identified: i) shear failure due to bed-joint sliding; ii) cracking due to diagonal tension; iii) diagonal compression failure and iv) corner crushing of the infill. The predicted failure mode, the related strength and the stiffness change noticeably from one model to another [13].

In this study, five strut models have been taken into account (Table 1). Most of them takes into account different failure modes and are derived through comparisons with experimental results.

\begin{tabular}{lcccc}
\hline Reference & $\mathrm{R}_{\mathrm{s}}^{(1)}$ & $\mathrm{R}_{\mathrm{dt}}^{(2)}$ & $\mathrm{R}_{\mathrm{dc}}^{(3)}$ & $\mathrm{R}_{\mathrm{cc}}{ }^{(4)}$ \\
\hline Decanini and Fantin [14] & $\mathrm{Y}$ & $\mathrm{Y}$ & $\mathrm{Y}$ & $\mathrm{Y}$ \\
Paulay and Priestley [15] & $\mathrm{Y}$ & $\mathrm{Y}$ & $\mathrm{Y}$ & $\times$ \\
Priestley and Calvi [16] & $\mathrm{Y}$ & $\mathrm{Y}$ & $\mathrm{Y}$ & $\mathrm{Y}$ \\
Saneinejad and Hobbs [17] & $\mathrm{Y}$ & $\mathrm{Y}$ & $\times$ & $\mathrm{Y}$ \\
FEMA 306 [18] & & Shear strength & \\
Panagiotakos and Fardis [19] & &
\end{tabular}

(1) Failure due to bed-joint sliding; (2) Cracking due to diagonal tension; (3) Failure due to diagonal compression; (4) Failure due to corner crushing

Table 1: Failure modes taken into account in the considered strut models.

Predictive equations for the strength are listed in Table 2, respectively. In the Table 2, the strut axial strength, $R$, is reported. The lateral strength, $H$, is then given by the following equation:

$$
H=R \cos (\theta)
$$

In the model by Decanini and Fantin [14] four failure modes are considered (equation 2 to 5). In Table 2, $R_{s}$ is the strength in the bed-joint sliding failure mode; $R_{d t}$ is the strength in the diagonal tension failure mode; $R_{d c}$ is the strength in the diagonal compression failure mode and $R_{c c}$ is the strength in the corner compression failure mode; $d$ is the length of the strut; $t$ is the masonry thickness; $\theta$ is the strut angle of inclination; $f_{m}^{\prime}$ is the masonry compressive strength; $\tau_{0}$ is the basic shear strength of bed joints; $\tau_{m 0}$ is the shear strength evaluated through diagonal compression tests; $\sigma_{y}$ is the vertical stress; $w$ is the width of the equivalent strut; $\lambda_{h}$ is a non-dimensional parameter and $k_{1}$ and $k_{2}$ are equation coefficients (see Table 3).

According to Paulay and Priestley [15] the strut force to initiate sliding in infill panels, $R_{s}$, depends on the shear friction stress and on the aspect ratio of the panel, the coefficient of friction is assumed equal to 0.3 (equation 6). The diagonal compression strength (equation 7) is function of the vertical contact length, $z$, between infill and column. In Priestley and Calvi [16] the diagonal tension cracking failure is also considered. This failure mode does not produce itself the infill collapse, however the in-plane damage due to cracking contributes to the outof-plane expulsion of the panel. The diagonal force, which induces diagonal tension cracking, is evaluated using the relationship for tensile stress in a disk loaded along a diameter (equation 8). 


\begin{tabular}{|c|c|c|}
\hline Reference & Strut Axial Strength & \\
\hline \multirow{4}{*}{ Decanini and Fantin [14] } & $R_{s}=\left[(1.2 \operatorname{sen} \theta+0.45 \cos \theta) \tau_{0}+0.3 \sigma_{y}\right] t d$ & $(2)$ \\
\hline & $R_{d t}=\left(0.6 \tau_{m 0}+0.3 \sigma_{y}\right) t d$ & (3) \\
\hline & $R_{d c}=\frac{1.16 \tan \theta}{2} f_{m}^{\prime} t d$ & (4) \\
\hline & $R_{c c}=\frac{1.12 \operatorname{sen} \theta \cos \theta}{\lambda_{h}^{0.88}} f_{m}^{\prime} t d$ & (5) \\
\hline \multirow{3}{*}{$\begin{array}{l}\text { Paulay and Priestley [15] } \\
\text { Priestley and Calvi [16] }\end{array}$} & $R_{s}=\frac{\tau_{0}}{1-0.3(h / l)} t d$ & (6) \\
\hline & $R_{d c}=\frac{2}{3} z t f_{m}^{\prime} \sec \theta \quad z=\frac{\pi}{2} \frac{h}{\lambda_{h}}$ & (7) \\
\hline & $R_{d t}=\frac{\pi}{2} t d f_{t m}^{\prime}$ & (8) \\
\hline \multirow{5}{*}{ Saneinejad and Hobbs [17] } & $R_{s}=\min \left\{\frac{\gamma \tau_{0} t d}{1-0.45 \tan \theta^{\prime}}\right.$ & (9) \\
\hline & $(0.83 \gamma t d(0.83$ in $M P a)$ & \\
\hline & $R_{d t}=2 \sqrt{2} t h_{m} f_{t}^{\prime} \cos \theta$ & (10) \\
\hline & $R_{d c}=\frac{0.5 h_{m} t f_{a}}{\cos \theta} \quad f_{a}=0.39 f_{m}^{\prime}\left[1-\left(\frac{l_{e f f}}{40 t}\right)^{2}\right]$ & (11) \\
\hline & $R_{c c}=\frac{\left(1-\alpha_{c}\right) \alpha_{c} h t \sigma_{c}+\alpha_{b} l t \tau_{b}}{\cos \theta}$ & $(12)$ \\
\hline \multirow{3}{*}{ FEMA 306 [18] } & $R_{s}=\frac{\left(\tau_{0}+\mu \sigma_{y}\right) l t}{\cos \theta}$ & (13) \\
\hline & $R_{d t}=2 \sqrt{2} t h_{m} f_{t}^{\prime} \cos \theta$ & (14) \\
\hline & $R_{c c}=w t f_{m 90}^{\prime}$ & $(15)$ \\
\hline Panagiotakos and Fardis [19] & $R_{s}=\frac{1.3 \tau_{c r} l_{m} t}{\cos \theta}$ & (16) \\
\hline
\end{tabular}

Table 2: Predictive equations for the strut axial strength.

In the analytical method developed by Saneinejad and Hobbs [17] all failure modes are considered. In equations 9 to 12 (Table 2), $\gamma$ is the load factor and $\theta^{\prime}$ is depicted in Figure 1. Diagonal cracking of the infill is regarded as a serviceability limit state; however, it may be related to a collapse limit state because presence of diagonal cracking in both diagonals accelerates the out-of-plane failure of the infill. For the cracking load, equation 10 is suggested, 
where $f_{t}^{\prime}$ is the tensile strength of infill material. The diagonal compression strength is given by equation 11 , where $f_{a}$ is the permissible stress, which takes into account the out-of-plane buckling and $l_{\text {eff }}$ is the effective length of the strut (Figure 1). From the above formula it results that the permissible stress is negative when the thickness of the infill is smaller than $2.5 \%$ of the effective length. Finally, in equation 12, $\alpha_{c} h$ and $\alpha_{b} l$ are the contact lengths between infill and columns and infill and beam, respectively, $\sigma_{c}$ and $\tau_{b}$ are the column-infill and beaminfill contact stresses.

Three potential in-plane failure modes are considered in FEMA 306 [18]. The MohrCoulomb failure criteria is used to assess the sliding-shear capacity of the infill, the corresponding strut resistance may be calculated by means of equation 13 , where $\tau_{0}$ may be taken as $1 / 40$ times the compressive strength and $\mu$ is the coefficient of friction along the bed joints. The diagonal tension strength in [18] is the same as suggested by Saneinejad and Hobbs, where $f_{t}^{\prime}$ may be taken as $1 / 20$ of the compressive strength in the horizontal direction, $f_{m 90}^{\prime}$. For corner compression failure, a modified version of the method proposed by Stafford-Smith and Carter [20] is suggested (equation 15).

Finally, Panagiotakos and Fardis [19] suggest calculate the infill ultimate strength by equation 16 , where $\tau_{c r}$ is the masonry cracking strength as determined from diagonal compression tests.

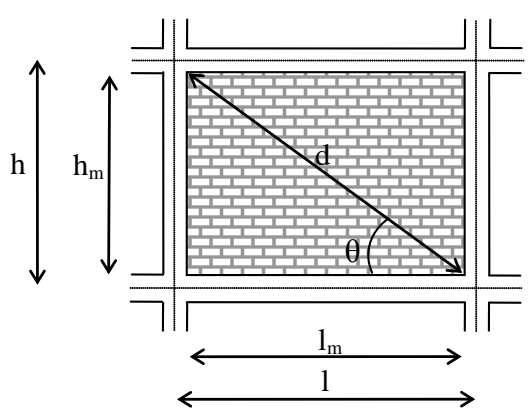

(a)

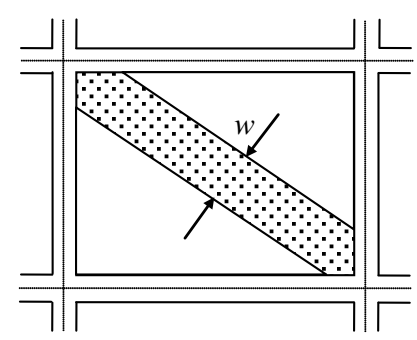

(b)

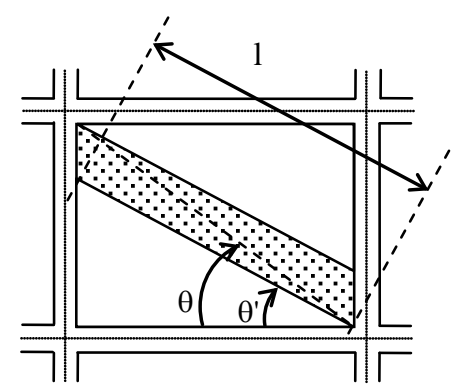

(c)

Figure 1: Equivalent strut model: a) in-plane geometrical features; b) equivalent strut; c) Saneinejad and Hobbs geometrical parameters [17].

The axial stiffness of the strut, $k$, is generally calculated as a function of the strut width, $w$, according to the following equation:

$$
k=\frac{E_{m} t w}{d}
$$

where $E_{m}$ is the modulus of elasticity of masonry, $t$ is the panel thickness and $d$ is the strut length. The lateral stiffness, $k_{m}$, can be calculated as:

$$
k_{m}=\frac{E_{m} t w}{d} \cos ^{2}(\theta)
$$

Equations proposed to estimate $w$ are reported in Table 3. The parameter $\lambda_{h}$, used in some of these expressions, is a non-dimensional parameter introduced by Stafford-Smith [7] to take into account the influence of the relative stiffness of the frame and the infill:

$$
\lambda_{h}=\sqrt[4]{\frac{E_{m} t \operatorname{sen} 2 \theta}{4 E I h_{m}}} h
$$


where: $E$ is the modulus of elasticity of the frame material and $I$ is the moment of inertia of columns (see above for definitions of other parameters).

\begin{tabular}{|c|c|c|c|c|}
\hline Reference & \multicolumn{4}{|c|}{ Equivalent strut width } \\
\hline \multirow{3}{*}{ Decanini and Fantin [14] } & \multirow{3}{*}{$w=\left(\frac{k_{1}}{\lambda_{h}}+k_{2}\right) a$} & \multirow{3}{*}{ (20) } & \multicolumn{2}{|c|}{$\begin{array}{c}\text { for } \lambda_{h}<3.14 \\
k_{1}=1.3 \quad k_{2}=-0.178\end{array}$} \\
\hline & & & \multicolumn{2}{|c|}{$\begin{array}{c}\text { for } \quad 3.14<\lambda_{h}<7.85 \\
k_{1}=0.707 \quad k_{2}=0.01\end{array}$} \\
\hline & & & \multicolumn{2}{|c|}{$\begin{array}{c}\text { for } 7.85<\lambda_{h} \\
k_{1}=0.47 \quad k_{2}=0.04\end{array}$} \\
\hline $\begin{array}{l}\text { Paulay and Priestley [15] } \\
\text { Priestley and Calvi [16] }\end{array}$ & \multicolumn{4}{|c|}{$w=\frac{d}{4}$} \\
\hline $\begin{array}{l}\text { Saneinejad and Hobbs } \\
\text { [17] }\end{array}$ & $w=\min$ & \multicolumn{2}{|c|}{$\begin{array}{c}\cos \theta \\
0.5 \frac{h_{m} \frac{f_{a}}{f_{c}}}{\cos \theta}\end{array}$} & $(22)$ \\
\hline FEMA 306 [18] & $w=$ & $5\left(\lambda_{h}\right)$ & & (23) \\
\hline
\end{tabular}

Table 3: Predictive equations for the strut width.

The expression by Decanini and Fantin [14] provides the secant stiffness of the strut. The equation suggested by Paulay and Priestley [15], which gives a conservative value of the width, is recommended for a lateral force level of $50 \%$ of the ultimate capacity. The value suggested by Saneinejad and Hobbs [17] is related to the attainment of the resisting loads $R_{c c}$ and $R_{d c}$. The formula reported in FEMA 306 [18], which was initially proposed by Mainstone [21], was found suitable for the estimation of the infill secant stiffness if the masonry elastic modulus in the horizontal direction is used [19].

\section{DATABASE USED IN THE STUDY}

Experimental results available in the literature are used in this study to assess the selected strut models. The whole dataset, composed of 162 test specimens (Table 4), includes different types of frame-infill systems. With regard to reinforced concrete frames, both infilled frames and confined masonry structures are considered. In the infilled frames the masonry panel is built after the frame, whereas in confined masonry the panel is built earlier. The difference between confined masonry and infilled frame systems is twofold: i) in confined masonry, a stronger adherence between masonry and RC columns and beams develops compared to that present in infilled frames; ii) in confined masonry buildings the column and beam cross sections are generally smaller than in infilled frame buildings.

Concerning the walls, in $60 \%$ of the test specimens the masonry is made up of hollow units (vertical or horizontal hollows), in the other $40 \%$ the masonry is made up of solid bricks or blocks. The aspect and the slenderness ratios of the infills vary noticeably: the former is in the range $0.48-2.95$, the latter varies between 5.33 and 25.78 . However, in $80 \%$ of the specimens 
the aspect and slenderness ratios are less than 1 and 15, respectively. This values can be considered representative of sizes present in common existing infilled framed buildings. Horizontal loads are applied monotonically or cyclically in 34 and 128 experimental tests, respectively. Cyclic loads are generally applied statically with force-controlled or, more often, displacement-controlled procedures. Pseudo-dynamic and dynamic tests are performed in 12 experimental tests.

The whole database is used to assess the capability of different strut models to estimate the infill strength. As for the assessment of the infill stiffness, only the tests for which the horizontal force versus horizontal displacement curves were available have been used. The reduced database includes 101 specimens.

\begin{tabular}{lll}
\hline Reference & N. of test & Structure ${ }^{(1)}$ \\
\hline Benjamin and Williams, 1958, [22] & 8 & RC \\
Jorquera, 1964, [23] & 17 & CM \\
Leuchars and Scrivener, 1976, [24] & 2 & RC \\
Jurina, 1977, [25] & 3 & RC \\
Parducci et al., 1980 [26], 1982 [27] & 6 & RC \\
Liu et al., 1982, [28] & 9 & RC \\
Srinivasa Rao et al., 1982, [29] & 3 & RC (1), CM (2) \\
Gallegos and Casabonne, 1984, [30] & 2 & RC \\
Zarnic and Tomazevic, 1984 [31], 1986 [32] & 11 & RC \\
Decanini et al., 1985, [33] & 3 & CM \\
Michelini et al., 1986, [34,35] & 9 & CM \\
Valiasis and Stylianidis, 1989 [36] & 16 & RC \\
Pires, 1990, [37] & 6 & RC (3), CM (3) \\
Kato et al., 1992, [38] & 4 & CM \\
Meherabi et al., 1996, [39] & 10 & RC \\
Crisafulli, 1997, [11] & 2 & RC \\
Calvi e Bolognini, 2001, [40] & 8 & RC \\
Colangelo, 2005, [41] & 11 & RC \\
Hashemi and Mosalam, 2006, [42] & 1 & RC \\
Bergami, 2007, [43] & 2 & RC \\
Kakaletsis and Karayannis, 2008, [44] & 2 & RC \\
Stavridis, 2009, [45] & 2 & RC \\
Tasnimi and Mohebkhahb, 2011, [46] & 1 & Steel \\
Yuksel, 2011, [47] & 2 & RC \\
Sigmund and Penava, 2012, [48] & 1 & RC \\
Di Trapani, 2013, [49] and Cavaleri et al., 2005, [50] & 12 & RC \\
Markulak et al., 2013, [51] & 6 & Steel \\
Guidi et al., 2013, [52] & 1 & RC \\
Morandi et al., 2014, [53] & 2 & RC \\
\hline (1) RC=Reinforced Concrete, CM=Confined Masonry & & \\
\hline
\end{tabular}




\section{RESULTS AND DISCUSSION}

Equations reported in Table 2 are used to predict the lateral strength of infills. The predictions are then compared with the experimental values of lateral strength. The experimental results always concern the infill-frame systems; therefore, a basic preliminary step was the estimation of the contribution of infill to the total lateral resistance. This is made herein by calculating the difference between the infilled frame and the bare frame. In those cases in which the bare frames were not available, an approximated frame backbone curve has been obtained using the model proposed by Haselton [54].

The ratio between predicted and experimental strength is calculated for the five strut models. The exponential of the logarithmic mean, $e^{\mu_{l n}}$, and the logarithmic standard deviation, $\sigma_{l n}$, of this ratio are then estimated. The former represents the median values under the hypothesis of a lognormal distribution, the latter approximates the coefficient of variation and gives a measure of the dispersion. These values are reported in Table 5 for the whole database and for data samples clustering different type of structures, i.e., infilled reinforced concrete frames, confined masonry systems and infilled steel frames.

The model proposed and Priestley [15] and Priestley and Calvi [16] provides, on the average, a good estimate of the actual values. However, with the exception of the steel frames set, a large dispersion is noted, being the logarithmic standard deviation between 0.453 and 0.534 . The models proposed by Decanini and Fantin [14] and by Panagiotakos and Fardis [19] give, in general, the lowest dispersion for infilled RC frames and confined masonry, whereas the Paulay and Priestley [15] and Priestley and Calvi [16] model furnishes the best results for steel frames, in terms of both mean value and logarithmic standard deviation.

\begin{tabular}{|c|c|c|c|c|c|}
\hline & $\mathrm{DF}^{(1)}$ & $\mathrm{PF}^{(2)}$ & $\mathrm{PPC}^{(3)}$ & $\mathrm{SH}^{(4)}$ & FEMA $^{(5)}$ \\
\hline \multicolumn{6}{|l|}{ Whole database } \\
\hline$e^{\mu_{l n}}$ & 0.848 & 1.350 & 1.071 & 0.624 & 0.698 \\
\hline$\sigma_{l n}$ & 0.407 & 0.409 & 0.517 & 0.580 & 0.571 \\
\hline \multicolumn{6}{|l|}{ Infilled RC frames } \\
\hline$e^{\mu_{\ln }}$ & 0.871 & 1.389 & 1.010 & 0.652 & 0.708 \\
\hline$\sigma_{l n}$ & 0.439 & 0.444 & 0.534 & 0.617 & 0.608 \\
\hline \multicolumn{6}{|l|}{ Confined masonries } \\
\hline$e^{\mu_{l n}}$ & 0.808 & 1.277 & 1.284 & 0.567 & 0.709 \\
\hline$\sigma_{l n}$ & 0.294 & 0.285 & 0.453 & 0.472 & 0.456 \\
\hline \multicolumn{6}{|l|}{ Infilled steel frames } \\
\hline$e^{\mu_{\ln }}$ & 0.701 & 1.151 & 1.045 & 0.517 & 0.492 \\
\hline$\sigma_{l n}$ & 0.252 & 0.253 & 0.177 & 0.268 & 0.281 \\
\hline
\end{tabular}

Table 5: Predicted/experimental strength ratios: $e^{\mu_{l n}}=$ exponential of the logarithmic mean, $\sigma_{l n}=$ logarithmic standard deviation.

The predicted lateral strengths are plotted in Figure 2 versus the experimental ones. Different colours indicate different structural systems: blue markers are used for infilled reinforced concrete frames, red markers for confined masonries and black markers for infilled steel frames. Linear regression curves, related to the whole database, and coefficients of determination, $R^{2}$, are also reported in the figure. 

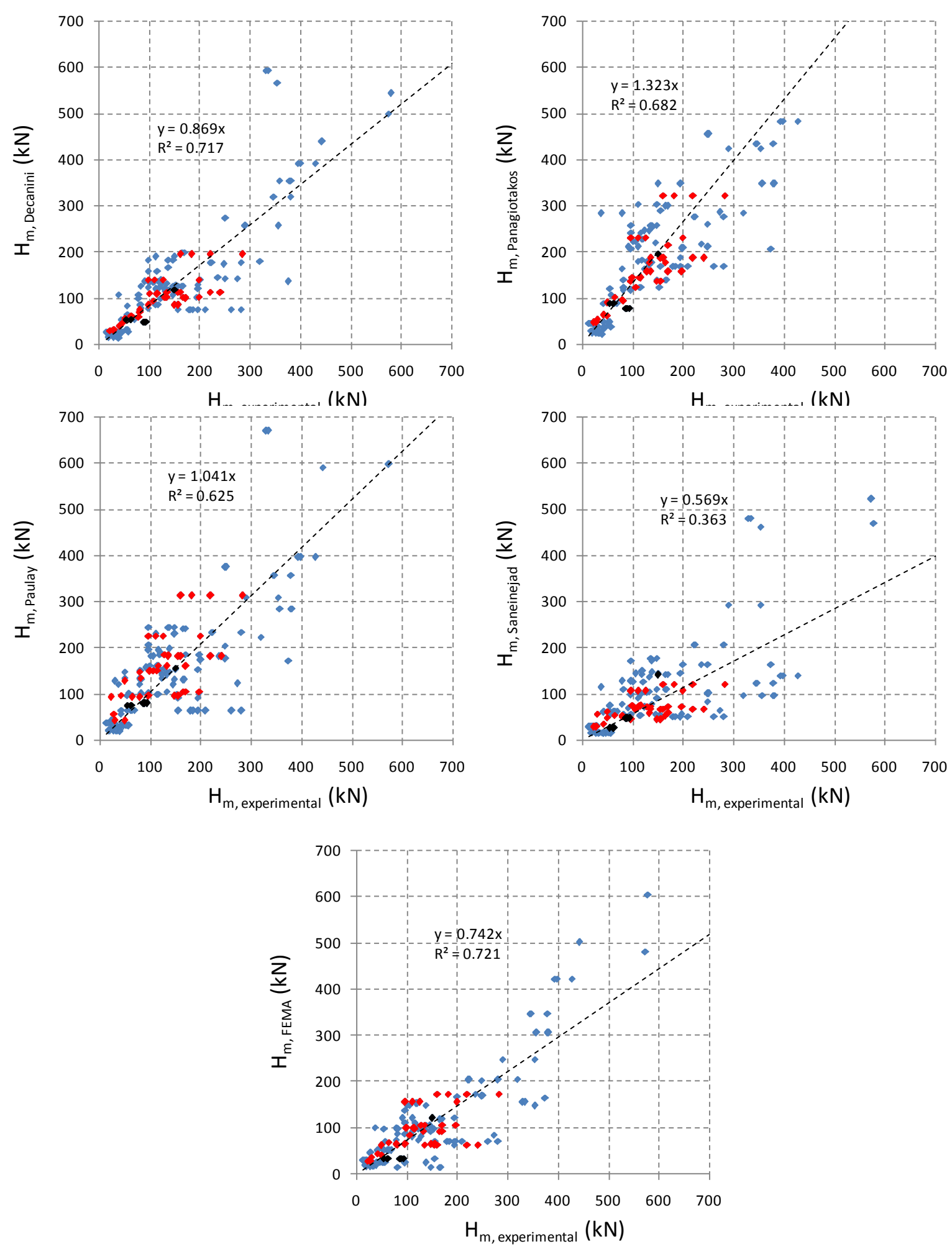

Figure 2: Lateral strength of infill: predictions vs. experimental values. Blue markers: infilled reinforced concrete frames; red markers: confined masonry; black markers: infilled steel frame.

It is noted that: strength values predicted by Panagiotakos and Fardis [19] are higher than the actual (experimental) ones; the model proposed by Paulay and Priestley [15] and Priestley and Calvi [16] is almost unbiased; the other models tend, on the average, to underestimate the 
infill strength. The highest and the lowest coefficients of determination are obtained, considering the whole dataset, using the formulation proposed by the Decanini and Fantin [14] and Saneinejad and Hobbs [17], respectively.

The comparison between predicted and experimental lateral stiffness is made considering the reduced database. Formulas reported in Table 3 and equation 18 are used to calculate the predicted values. The experimental stiffness is calculated as the elastic stiffness of an equivalent bilinear system, obtained through the energy equivalence criterion up to the peak lateral load $\left(H_{m}\right)$. Figure 3 shows the comparison between predicted and experimental results. The use of various formulas leads to different values of the equivalent width, and, therefore, of the strut stiffness. For example, the equation in FEMA [18] gives a much more deformable strut compared to the other models. Moreover, differences between predicted and experimental values are significant, showing that none of the considered models is able to predict the infill stiffness adequately. For the confined masonry frames, all of the models predict values of the stiffness lower than the actual ones. The dispersion of the data is noticeable, coefficient of variations varying between 1.7 and 2.0. These results show the great uncertainty in the assessment of infills stiffness.
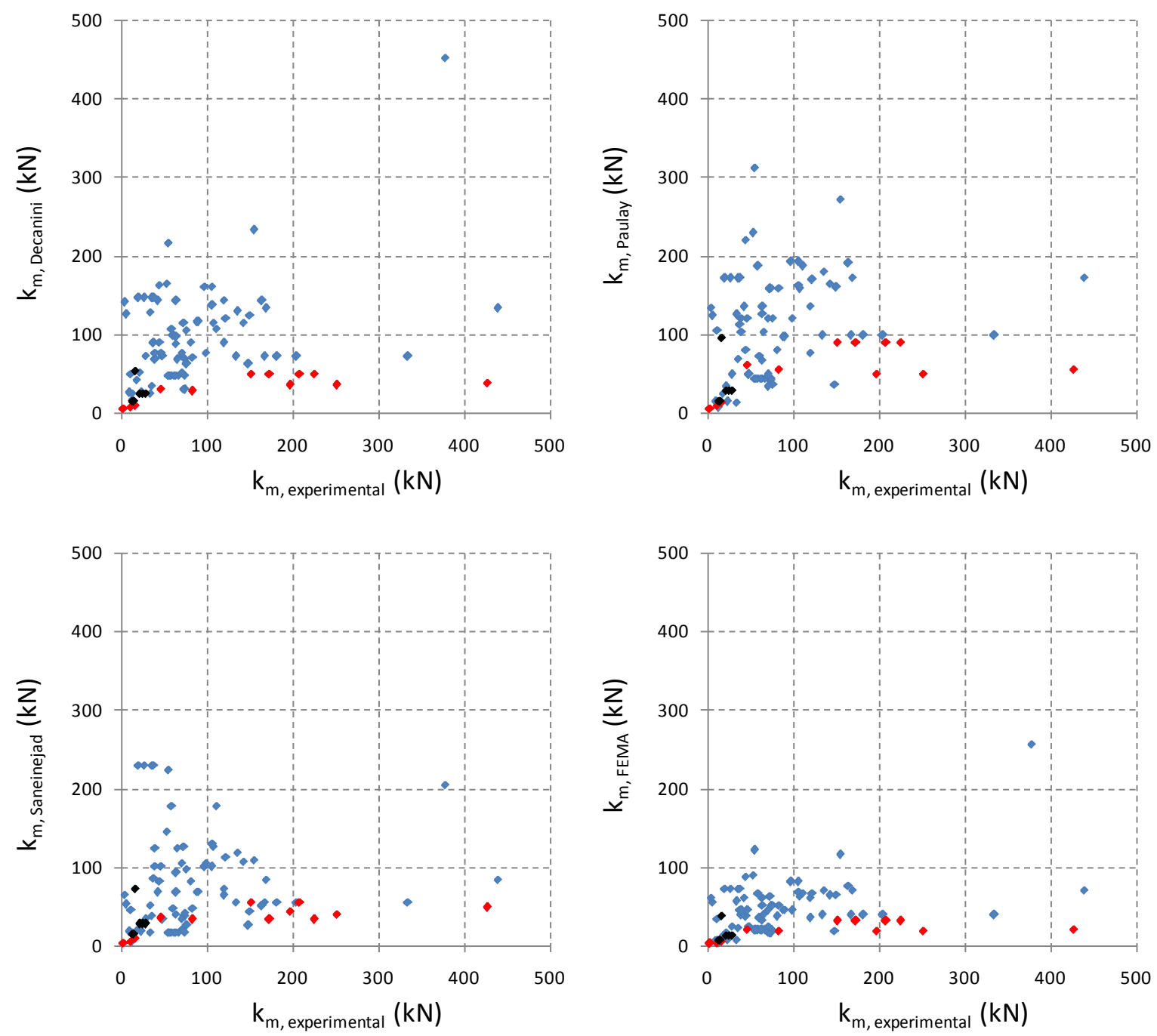

Figure 3: Lateral stiffness of infill: prediction vs. experimental values. Blue markers: infilled reinforced concrete frames; red markers: confined masonry; black markers: infilled steel frame. 


\section{CONCLUSIONS}

In this work, 162 experimental tests have been considered to evaluate the adequacy of various strut models. The database includes different types of masonry walls, which are made of hollow or solid bricks or blocks, and different types of frame-infill systems: 116 infilled reinforced concrete frames, 39 confined masonry structures and 7 infilled steel frames.

The assessment of the contribution of infills to the lateral stiffness and strength of the experimental tests was a basic preliminary step. This assessment was made by calculating the difference between the infilled frame and the bare frame. In those cases in which the bare frame was not available, several assumptions, like for example that of rigid beams, have been made to calculate the bare frame backbone curves. Stiffness and strength predictions have been calculated considering five strut models. Such models require the knowledge of the geometrical and mechanical characteristics of the frame and the infill. In some cases, the required parameters were not assessed experimentally, such as the masonry shear strength and the horizontal compressive strength. When not available, these features have been calculated here by means of empirical equations.

The comparison between predicted and actual lateral strengths shows that the models by Paulay and Priestley [15], Priestley and Calvi [16] and Decanini and Fantin [14] give the best predictions, with the former having the advantage of being almost unbiased and the latter giving the lowest dispersion. The strength predicted by Panagiotakos and Fardis [19] is, on the average, higher than the actual one, while the other models $([17,18])$ underestimate the infill strength. Concerning the stiffness, none of the models reproduce satisfactorily the actual values. Differences between predicted and experimental values are significant, showing the inadequacy of all the considered equations. Given the large differences obtained using different formulations, much attention should be paid in the model selection.

On the basis of the reported results, it can be concluded that the high variability of the material and the large number of parameters involved, make the reliability of the modelling very hard to obtain. However, the significant contribution of infill walls in the behaviour of infilled frames requires the continuation of research in this area. Finally, other aspects not taken into account in this study, such as the modelling of the hysteretic behaviour, need to be further investigated.

\section{ACKNOWLEDGEMENTS}

The financial support of the Ministry of the Instruction, University and Research of Italy (MIUR) is gratefully acknowledged. This work has been partially carried out under the program “Dipartimento di Protezione Civile - Consorzio RELUIS 2017, Area Tematica 1".

\section{REFERENCES}

[1] L. Liberatore, L.D. Decanini, "Effect of infills on the seismic response of high-rise RC buildings designed as bare according to Eurocode 8”, Ingegneria Sismica, 28(3): 7-23, 2011.

[2] L.D. Decanini, L. Liberatore, F. Mollaioli, "Damage potential of the 2009 L'Aquila, Italy, earthquake”, Journal of Earthquake and Tsunami, 6(3), 1250032:1-32, 2012.

[3] F. Di Trapani, G. Macaluso, L. Cavaleri, M. Papia, "Masonry infills and RC frames interaction: literature overview and state of the art of macromodeling approach", European Journal of Environmental and Civil Engineering, 19(9), 1059-1095, 2015. 
[4] N. Tarque, L. Candido, G. Camata, E. Spacone, "Masonry infilled frame structures: state-of-theart review of numerical modelling”, Earthquakes and Structures, 8(3), 733-759, 2015.

[5] P.B. Shing, A.B. Mehrabi, "Behaviour and analysis of masonry-infilled frames", Progress in Structural Engineering and Materials, 4(3), 320-331, 2002.

[6] L. Liberatore, M. Bruno, O. AlShawa O., M. Pasca, L. Sorrentino, "Finite-discrete element modelling of masonry infill walls subjected to out-of-plane loads", 7th European Congress on Computational Methods in Applied Sciences and Engineering (ECCOMAS), 3: 5219-5229, 2016.

[7] B. Stafford Smith, "Lateral stiffness of infilled frames”, Journal of Structural Division, ASCE, 88, no. ST6, 183-199, 1962.

[8] R.J. Mainstone, “On stiffness and strength of infilled frames”, Proceedings of Institution of Civil Engineers, n. 7360, 57-90, 1971.

[9] L.D. Decanini, L. Liberatore, F. Mollaioli, "Strength and stiffness reduction factors for infilled frames with openings”, Earthquake Engineering and Engineering Vibration, 13(3), 437-454, 2014.

[10] V. Thiruvengadam, "On the natural frequencies of infilled frames", Earthquake Engineering and Structural Dynamics, 31(2), 44-46, 1985.

[11] F.J. Crisafulli, Seismic behaviour of reinforced concrete structures with masonry infills, $\mathrm{PhD}$ Thesis, University of Canterbury, Christchurch, New Zealand, 1997.

[12] P. Haldar, Y. Singh, D.K. Paul, "Identification of seismic failure modes of URM infilled RC frame buildings", Engineering Failure Analysis, 33: 97-118, 2013.

[13] L. Liberatore, F. Mollaioli, "Influence of masonry infills modelling on the seismic response of reinforced concrete frames”, 15th International Conference on Civil, Structural and Environmental Engineering Computing (Civil-Comp Proceedings), 108, n. 87, 2015.

[14] L.D. Decanini, G.E. Fantin, "Modelos simplificados de la mampostería incluida en porticos. Características de rigidez y resistencia lateral en estado límite”, Jornadas Argentinas de Ingenierìa Estructural, 817-836, 1987.

[15] T. Paulay, M.J.N. Priestley, Seismic design of reinforced concrete and masonry buildings, John Wiley \& Sons, Inc., 1992.

[16] M.J.N. Priestley, M. Calvi, "Towards a capacity-design assessment procedure for reinforced concrete frames”, Earthquake Spectra, 7(3), 413-437, 1991.

[17] A. Saneinejad, B. Hobbs, "Inelastic design of infilled frames", Journal of Structural Engineering, ASCE, 121(4), 634-50, 1995.

[18] FEMA 306, Evaluation of earthquake damaged concrete and masonry wall buildings - basic procedures manual, prepared by The Applied Technology Council, 1998.

[19] T.B. Panagiotakos, M.N. Fardis, "Seismic response of infilled RC frames structures", 11th World Conference on Earthquake Engineering, n. 225, 1996.

[20] B. Stafford-Smith, C. Carter, “A method of analysis for infilled frames”, Proceedings of the Institute of Civil Engineers, 44, 31-48, 1969.

[21] R.J. Mainstone, "Supplementary note on the stiffness and strength of infilled frames", Building Research Station, CP 13/74, Building Research Establishment, U.K., 1974.

[22] J.R. Benjamin, H.A. Williams, "The behavior of one-story brick shear walls", Journal of the Structural Division, Proc. ASCE, n. 1723, ST 4, 1958.

[23] L. Jorquera, "Estudio esperimental sobre la resistencia de muros de albanileria sometidos a cargas horizontales”, Revista de IDIEM, 3, 1964. 
[24] J.M. Leuchars, J.C. Scrivener, “Masonry infill panels subjected to cyclic in-plane loading”, Bulletin of the New Zealand Society for Earthquake Engineering, 9(2):122-131, 1976.

[25] L. Jurina, "Pareti in muratura soggette ad azioni sismiche”, Costruire, 100: Tst/1-Tst/46, 1977.

[26] A. Parducci, M. Mezzi,. "Repeated horizontal displacements of infilled frames having different stiffness and connecting systems - experimental analysis”, 7th World Conference on Earthquake Engineering, Istanbul, Turkey, 1980.

[27] A. Parducci, A. Checchi, "Contributo delle tamponature di mattoni alla resistenza sismica delle strutture intelaiate”, 6th International Brick Masonry Conference, Rome, 1982.

[28] X. Liu, H. Zhang, J. Liu, L. Liu, "Experimental investigation and aseismic safety evaluation of brick masonry buildings with R/C tie columns", $7^{\text {th }}$ European Conference on Earthquake Engineering, , Athens, Greece, 5: 197-204, 1982.

[29] P. Srinivasa Rao, H. Achyutha, R. Jagadish, N. Devanarayanan, "Influence of methods of construction on the behaviour of infilled frames", 6th International Brick and Block Masonry Conference, Rome, Italy, 549-560, 1982.

[30] H. Gallegos, C. Casabonne, “Cyclic test of three different types of masonry walls”, Third International Symposium on Wall Structure, Warsaw, Poland, 1984.

[31] R. Zarnic, M. Tomazevic, "The Behaviour of Masonry Infilled Reinforced Concrete Frames Subjected to Cyclic Lateral Loading”, $8^{\text {th }}$ World Conference on Earthquake Engineering, San Francisco, p 863:870, 1984

[32] R. Zarnic, M. Tomazevic, T. Velechovsky, "Experimental study of methods for repair and strengthening of masonry infilled reinforced concrete frame", $8^{\text {th }}$ European Conference on Earthquake Engineering, Lisbon, Portugal, 5: 11.1/41-48, 1986.

[33] L.D. Decanini, A. Payer, C. Serrano, R. Terzariol, "Investigacion experimental sobre el comportamiento sismorresitente de prototipos a escala natural de muros de mamposteria encadenada”, Memoria B Ingenieria Estructural, colloquia 85, Tomo VI, 1985.

[34] R.J. Michelini et al. "Influencia de la acciòn vertical en el comportamiento estructural de paneles de mamposteria bajo el efecto de cargas orizontales", $4^{a s}$ Jornadas Chilenas de Sismologia e Ingenieria Antisismica, Viña del Mar, Chile, Tomo 2: H119-138, 1986.

[35] R.J. Michelini, L.A. Olivencia, D.A. Forni, N.G. Maldonado, "Comportamiento ante acciones horizontales de mamposteria reparada", $4^{a s}$ Jornadas Chilenas de Sismologia e Ingenieria Antisismica, Viña del Mar, Chile, Tomo 1: D96-115, 1986.

[36] T.N. Valiasis, K.C. Stylianidis, "Masonry Infilled R/C/ Frames under Horizontal Loading Experimental Results”, European Earthquake Engineering, 3: 10-20, 1989.

[37] F.M. Pires, Influência das paredes de alvenaria no comportamento de estrututras reticuladas de betão armado sujeitas a aç̧ões horizontais, PhD Thesis. Laboratorio Nacional de Engenharia Civil, Lisboa, 1990.

[38] H. Kato, T. Goto, H. Mizuno, M. Iiba, "Cyclic loading tests of confined masonry wall elements for structural design development of apartment houses in the Third World", $10^{\text {th }}$ World Conference on Earthquake Engineering, Madrid, Spain, p. 3539:3544, 1992.

[39] A.B. Mehrabi, P.B. Shing, M.P. Schuller, J.L. Noland, "Experimental evaluation of masonryinfilled RC frames”, Journal of Structural Engineering, 122(3):228-237, 1996.

[40] G.M. Calvi, D. Bolognini, "Seismic response of reinforced concrete frames infilled with weakly reinforced masonry panels”, Journal of Earthquake Engineering, 5:153-185, 2001. 
[41] F. Colangelo, "Pseudo-dynamic seismic response of reinforced concrete frames infilled with non-structural brick masonry”, Earthquake Engineering and Structural Dynamics, 34(10):12191241, 2005.

[42] A. Hashemi, K.M. Mosalam, "Shake-table experiment on reinforced concrete structure containing masonry infill wall”, Earthquake Engineering and Structural Dynamics, 35:1827-1852, 2006.

[43] A.V. Bergami, Implementation and experimental verification of models for nonlinear analysis of masonry infilled r.c. frames, PhD Thesis, Roma Tre University, Rome, Italy, 2007.

[44] D.J. Kakaletsis, C.G. Karayannis, "Influence of masonry strength and openings on infilled R/C frames under cyclic loading”, Journal of Earthquake Engineering, 12(2):197-221, 2008.

[45] A. Stavridis, Analytical and experimental study of seismic performance of reinforced concrete frames infilled with masonry walls, PhD Thesis, University of California, San Diego, USA, 2009.

[46] A.A. Tasnimi, A. Mohebkhah, "Investigation on the behavior of brick-infilled steel frames with openings, experimental and analytical approaches”, Engineering Structures, 33: 968-980, 2011.

[47] E. Yuksel, P. Teymur, "Earthquake performance improvement of low rise RC buildings using high strength clay brick walls”, Bulletin of Earthquake Engineering, 9:1157-1181, 2011.

[48] V. Sigmund, D. Penava, "Experimental Study of Masonry Infilled R/C Frames with Opening”, 15th World Conference on Earthquake Engineering, Lisbon, Portugal, 2012.

[49] F. Di Trapani, Masonry infilled RC frames: Experimental results and development of predictive techniques for the assessment of seismic response, $\mathrm{PhD}$ Thesis, University of Palermo, Italy, 2013.

[50] L. Cavaleri, M. Fossetti, M. Papia, "Infilled frames: developments in the evaluation of cyclic behaviour under lateral loads”, Structural Engineering and Mechanics, 21(4):469-494, 2005.

[51] D. Markulak, I. Radić, V. Sigmund, "Cyclic testing of single bay steel frames with various types of masonry infill”, Engineering Structures, 51: 267-277, 2013.

[52] G. Guidi, F. da Porto, M. Dalla Benetta, N. Verlato, C. Modena, "Comportamento Sperimentale nel Piano e Fuori Piano di Tamponamenti in Muratura Armata e Rinforzata”, 15th Convegno ANIDIS L'Ingegneria Sismica in Italia, Padova, Italy, 2015.

[53] P. Morandi, S. Hak, G. Magenes, “In-plane Experimental Response of Strong Masonry Infills”, 9th International Masonry Conference, Guimarães, Portugal, 2014.

[54] C.B. Haselton, A.B. Liel, S.T. Lange, G.G. Deierlein, Beam-Column Element Model Calibrated for Predicting Flexural Response Leading to Global Collapse of RC Frame Buildings, PEER Report 2007/03, Pacific Earthquake Engineering Research Center, 2008. 